\title{
Corrigendum: Vascular development and hemodynamic force in the mouse yolk sac
}

\section{Monica D. Garcia and Irina V. Larina*}

Department of Molecular Physiology and Biophysics, Baylor College of Medicine, Houston, TX, USA

${ }^{*}$ Correspondence: larina@bcm.edu

Edited by:

James B. Hoying, Cardiovascular Innovation Institute, USA

Keywords: yolk sac, live imaging, vascular remodeling, mouse development, hemodynamics

\section{A corrigendum on}

Vascular development and hemodynamic force in the mouse yolk sac

by Garcia, M. D., and Larina, I. V. (2014). Front. Physiol. 5:308. doi: 10.3389/fphys. 2014.00308

The article "Vascular development and hemodynamic force in the mouse yolk sac" that is part of the research topic "Mechanotransduction and Development of Cardiovascular Form and Function" published 20 August 2014, is missing the following Acknowledgment Section:

\section{ACKNOWLEDGMENT}

This work is supported by the National Institutes of Health (R01HL120140 and U54HG006348) as well as by the Optical Imaging and Vital Microscopy core at Baylor College of Medicine.

Conflict of Interest Statement: The authors declare that the research was conducted in the absence of any commercial or financial relationships that could be construed as a potential conflict of interest.
Received: 25 November 2014; accepted: 28 November 2014; published online: 12 December 2014.

Citation: Garcia MD and Larina IV (2014) Corrigendum: Vascular development and hemodynamic force in the mouse yolk sac. Front. Physiol. 5:492. doi: 10.3389/fphys.2014.00492

This article was submitted to Vascular Physiology, a section of the journal Frontiers in Physiology.

Copyright (C) 2014 Garcia and Larina. This is an openaccess article distributed under the terms of the Creative Commons Attribution License (CC BY). The use, distribution or reproduction in other forums is permitted, provided the original author(s) or licensor are credited and that the original publication in this journal is cited, in accordance with accepted academic practice. No use, distribution or reproduction is permitted which does not comply with these terms. 